\section{Assessing ethical and social issues of transtelephonic electrocardiography (TTEGG) in Chile}

\author{
Evaluación de los aspectos éticos y sociales de la \\ electrocardiografía transtelefónica (TTEGG) \\ en Chile
}

\author{
Avaliação das questões éticas e sociais da \\ eletrocardiografia transtelefônica (TTEGG) \\ no Chile
}

${ }^{1}$ Institut National de la Santé et de la Recherche Médicale, Paris, France. 2 Institute of Psychology, Ernst-Moritz-Arndt University, Greifswald, Germany.

3 Facultad de Medicina Universidad de Chile,

Santiago, Chile.

Correspondence E. Lamas

Institut National de la Santé et de la Recherche Médicale.

15, rue de l'École de Médecine 75006 Paris, France.

eugenia.lamas@inserm.fr

\begin{abstract}
The aim of this study was to focus on the ethical and social issues derived from the implementation of transtelephonic electrocardiography (TTECG) in the public healthcare sector in Chile, studying patients and healthcare provid ers' acceptance and expectations concerning: (a) TTECG effectiveness and safety; and (b) data protection issues, such as confidentiality, privacy and security. For this purpose, we developed two psychosocial surveys; the first was addressed to patients receiving transtelephonic electrocardiogram (either in the emergency services of hospitals or in distant primary care services) and the second one aimed at healthcare providers involved in either administering and/or interpreting it. Results included: (a) major acceptability of TTECG in terms of safety and security; (b) privacy and confidentiality of the patients were considered to be well protected; and (c) the patient-doctor relationship was not affected by this device.
\end{abstract}

Electrocadiography; Telemedicine; Patient Acceptance of Health Care; Ethics
Eugenia Lamas 1

Silvia Miguel 1

Holger Muehlan 2

Silke Schmidt 2

Rodrigo A. Salinas 3

\section{Resumen}

El objetivo de este estudio fue centrarse en los asuntos éticos y sociales, derivados de la aplicación de la tele-electrocardiografía (TTECG), en el sector público de salud en Chile, estudiando la aceptación y expectativas de pacientes y proveedores de servicios de salud en relación con: (a) eficacia y seguridad de la TTECG; y (b) cuestiones relacionadas con la protección de datos, tales como la confidencialidad, privacidad y seguridad. Para este fin, aplicamos dos encuestas psicosociales; la primera fue dirigida a los pacientes que reciben TTECG (ya sea en los servicios de urgencias de los hospitales, o en servicios de atención primaria alejados) y la segunda dirigida a los profesionales de la salud dedicados a la aplicación y/o interpretación. Los resultados fueron los siguientes: (a) gran aceptabilidad de TTECG en términos de seguridad y protección; (b) se considera que la privacidad y confidencialidad de los pacientes están protegidos; y (c) la relación entre los pacientes y el médico no se considera afectada por este dispositivo.

Electrocardiografía; Telemedicina; Aceptación de la Atención de Salud; Ética 


\section{Introduction}

Between 2001 and 2005 a comprehensive health care reform was passed by the Chilean parliament, and subsequently implemented by the government. The main aim of the reform was to reduce the huge inequalities in healthcare provision that affected the low-income, high-risk segment of the Chilean population 1 . The targeted inequalities in the system affected both access to healthcare for those in equal need, and health outcomes (as measured by, for example, life expectancy) ${ }^{2}$. The reform attempted a withdrawal from the neoliberal account of access to healthcare, imposed in the 1980s, and led to a more egalitarian one through a set of laws addressing access and funding of healthcare. One of the challenges for the implementation of equal access to healthcare, however, was the intricate geography of the country, with unequal distribution of technologies and trained human resources. That was the case of the use of thrombolysis for acute myocardial infarction: access to this life-saving intervention required the interpretation of electrocardiograms by trained specialists, who were not available in a large part of the country, being an invaluable tool for determining the probable effectiveness of thrombolytic therapy ${ }^{3}$. Transtelephonic electrocardiography (TTECG) was considered an effective answer to this challenge, and a national center with trained specialists was created in order to receive and analyze the records sent from rural areas to allow early diagnosis and treatment of myocardial infarction. TTECG involves the direct transmission of a locally recorded conventional ECG by telephone, which is decoded to a standard ECG on a computer in a cardiac center, where immediate professional ECG evaluation and interpretation is available 4 . The ECG is sent by telephone to the analysis center located in Santiago (the main metropolitan area of Chile), together with information about the patient including age, sex, relevant past medical history and chief complaint. When deemed necessary, the physician in the rural area is contacted by telephone, from the national center, to obtain further data. Attending physicians in rural areas are qualified to perform thrombolysis for acute myocardial infarction, and they are responsible for the diagnosis and immediate management of patients suffering this condition.

As part of the healthcare package comprised in this reform, TTECG was guaranteed for all those patients in which myocardial ischemia was suspected. A timely diagnosis of myocardial infarction allowed, thus, the use of thrombolysis for those patients in whom the use of this intervention was deemed as appropriate part of their care 5 .
Since the implementation of TTECG as part of routine care of patients in Chile, irrespective of their location, 523,371 TTECGs have been transmitted and interpreted by the centralized team, identifying 3,656 patients for whom thrombolysis could be a feasible treatment. A formal assessment of the impact of the Chilean Health Reform on the management and mortality of patients suffering from myocardial infarction has yielded favorable results, showing a decrease in hospital mortality of patients receiving this diagnosis 6 . The same authors propose that the timely use of thrombolysis could be one of the reasons behind this decrease in mortality 6 , and TTECG could be a factor allowing an increase in the use of this intervention.

The evaluation of any technology using telemedicine, however, should go beyond mere assessment of technical results and impact on health outcomes. Telemedicine raises issues in several domains, including ethical, psychosocial, and legal. Most evaluations, however, have focused on medical, organizational and technical aspects concerning its implementation 7, leaving aside a formal assessment of other equally relevant domains, such as data protection, confidentiality, acceptability and expectations of patients and healthcare providers involved in its administration. Effectiveness, safety, and data protection, thus, are only some of the aspects needing consideration, when judging the ethical appropriateness of healthcare innovations. Acceptability, expectations and the potential impact on the doctor-patient relationship should also be considered when evaluating the impact of new technologies using telemedicine; including the differences between the perception of the quality of the doctor-patient relationship and the relationship itself.

The aim of this study was to evaluate the acceptability and expectations of both patients and healthcare providers concerning data protection (confidentiality, privacy, and security), effectiveness and safety of TTEGG in the Chilean public sector.

\section{Methods}

A psychosocial survey was conducted, addressed to patients receiving a TTEGG and to those healthcare providers involved either in administering or interpreting it. A convenience sample was obtained from patients attending health care facilities in Rancagua, a city outside the main metropolitan area of Chile, in which there is no specialist available to interpret an electrocardiogram at the emergency department. Patients 
were selected from those attending the emergency department, seeking attention because of chest pain, to which a TTECG was administered. A convenience sample was obtained, also, from healthcare providers, comprising physicians, nurses and paramedics at the emergency room, and physicians and technicians working at the center of analysis located in the capital city of Chile, responsible for interpreting the electrocardiogram as a help to decision making at the point of care.

Two different questionnaires were applied to patients and healthcare providers. Both questionnaires were anonymous and self-administered. Patients as well as health care providers, were fully informed about the objectives of this study, and consented to participate to it.

The questionnaire applied to patients was composed of five closed-ended questions, concerning their level of understanding of the device, their expectations on safety, protection of privacy during the procedure and security of the data. The last question addressed their concern on how this telemedical approach could affect the quality of the doctor-patient relationship.

The questionnaire also included two openended questions: (1) "What did you feel when the TTECG was administered to you?", and (2) "What was your feeling when you knew that your personal data were going to be transmitted to a different location, and stored?".

On the other hand, the questionnaire administered to healthcare providers was composed of ten closed-ended items. The questions addressed their level of understanding of the device, their judgment on the easiness of use, accuracy and safety of the procedure, their expectations on the improvement of the healthcare provided by the use of TTECG and, finally, their judgment on how the use of this device could affect the doctorpatient relationship.

The responses to the closed-ended questions were tabulated, and analyzed using simple frequencies. The responses to the open-ended questions were analyzed using content analysis, in order to identify emerging themes, and then codified into relevant categories.

The Project was approved by the Ethics Research Committee of the Faculty of Philosophy and Humanities at the University of Chile.

\section{Results}

For this study, 14 patients and 32 healthcare providers were interviewed. Patients came from the Emergency Department of the Hospital Regional de Rancagua, which is the main public health- care facility located in the city of Rancagua, about $100 \mathrm{~km}$ south of Santiago. Healthcare providers included two physicians (Table 1), four nurses and seven technicians at the emergency room, and 19 paramedics working at the analysis center located in Santiago, responsible for interpreting the electrocardiogram (as a help to decision making at the point of care).

Table 1

Sample characteristics.

\begin{tabular}{lcccc}
\hline & \multicolumn{2}{c}{ Gender } & & Age \\
& Female & Male & Total & N (Mean) \\
\hline $\begin{array}{l}\text { Patients } \\
\text { Health care providers }\end{array}$ & 6 & 8 & 14 & 42 \\
Physicians & - & 2 & 2 & 47 \\
Nurses & 2 & 2 & 4 & 35 \\
Paramedics & 14 & 5 & 19 & 25 \\
Technicians & 4 & 3 & 7 & 26 \\
\hline
\end{tabular}

Patients answered the whole set of openended and closed-ended questions (Table 2). Regarding the open-ended questions, when they were asked about how they felt when the TTECG was administered as part of their care, the most frequently emerging theme was that they felt scared or uneasy, mainly because of their emergency health situation. Only two patients reported that they felt confident. When questioned about what their feeling was when they knew that their personal data were going to be transmitted to a different location and stored, as part of the technique, most patients recognized being indifferent about this issue. Only three patients felt either uneasy or distrustful concerning the security of their personal data. Regarding the closedended questions, a fair number of patients (5/14) recognized being "hardly informed" on this technique, and 9 of them said they were "informed". However, a vast majority of them considered the use of this device "as safe or very safe" (13/14). Most patients (12/14) considered that their privacy "was protected or very protected" during the procedure, and most of them (11/14) were also confident regarding the confidentiality of the data flowing during the procedure. No patient considered that the quality of the doctor-patient relationship worsened during the procedure, and 8 out of 14 felt that this relationship, actually, improved. 
Results for patients' survey $(n=14)$.

\begin{tabular}{|c|c|c|}
\hline Questions & Answers & Numbers \\
\hline \multirow[t]{4}{*}{ 1. Evaluate your level of knowledge regarding this device } & A. Uninformed & 0 \\
\hline & B. Hardly informed & 5 \\
\hline & C. Informed & 9 \\
\hline & D. Very informed & 0 \\
\hline \multirow{5}{*}{$\begin{array}{l}\text { 2. Evaluate your experience regarding the protection of privacy during } \\
\text { the procedure }\end{array}$} & A. Totally neglected & 0 \\
\hline & B. Neglected & 1 \\
\hline & C. Protected & 9 \\
\hline & D. Very protected & 3 \\
\hline & No answer & 1 \\
\hline \multirow{4}{*}{$\begin{array}{l}\text { 3. Evaluate your level of confidence regarding the confidentiality of the data } \\
\text { flowing during the procedure and its storage }\end{array}$} & A. Very unprotected & 1 \\
\hline & B. Unprotected & 2 \\
\hline & C. Protected & 10 \\
\hline & D. Very protected & 1 \\
\hline \multirow[t]{4}{*}{ 4. How do you estimate the level of security of this device? } & A. Unsafe & 0 \\
\hline & B. Hardly safe & 1 \\
\hline & C. Safe & 12 \\
\hline & D. Very safe & 1 \\
\hline \multirow{3}{*}{$\begin{array}{l}\text { 5. Do you believe that, with the use of this technology, the quality of the } \\
\text { doctor-patient relationship has: }\end{array}$} & A. Worsened & 0 \\
\hline & B. Not changed & 6 \\
\hline & C. Improved & 8 \\
\hline
\end{tabular}

On the other hand, as regards healthcare providers, all of them answered the whole set of closed-ended questions (Table 3). Most of them (27/32) recognized being either "informed or very informed" on the use of TTECG, and all of them considered the device either "easy or very easy" to use. Concerning their participation on registration and storage of obtained data, most of them (22/32) considered they were active or very active. Most healthcare providers (29/32) considered that the confidentiality of patients was "protected or very protected". A vast majority considered the device as safe or very safe (30/32). In the same way, most of them (20/32) declared having a high trust in the device, and all of them declared enough or significant confidence in the accuracy of the diagnosis sent as a response. A vast majority (27/32) considered that the quality of the healthcare they provide improved with the use of the device. Similarly, most of them (25/32) considered that patients benefited from this telemedical approach, and the same number considered that the doctor-patient relationship was improved.

\section{Discussion}

Chile is a country with a challenging geography, having some isolated regions where the provision of healthcare services in general and access to appropriate healthcare in terms of medical technologies and qualified human resources is difficult. As a result, the implementation of telemedicine devices turns out to be a useful tool to address these situations. This is why in the framework of the Chilean healthcare reform, devices such as the TTECG were implemented. As mentioned before, TTECG is a tool used to communicate primary health care centers in distant areas with one centralized facility with cardiologists in place who analyze the records received, thus allowing earlier diagnosis of acute myocardial infarction. Such early diagnosis should prompt faster thrombolysis or primary angioplasty. Furthermore, one of the most important features of TTECG in Chile is that it was used in emergency care, as it has been used in other countries 8,9.

Since the assessment of emerging health technologies must address also the context of its 
Results for healthcare providers' survey $(n=32)$.

\begin{tabular}{|c|c|c|}
\hline Questions & Answers & Numbers \\
\hline \multirow[t]{4}{*}{ 1. Evaluate the information you have available about this technique } & A. Not informed & 1 \\
\hline & B. Hardly informed & 4 \\
\hline & C. Informed & 22 \\
\hline & D. Very informed & 5 \\
\hline \multirow[t]{4}{*}{ 2. How easy is it to use this device? } & A. Very easy & 5 \\
\hline & B. Easy & 27 \\
\hline & C. Difficult & 0 \\
\hline & D. Very difficult & 0 \\
\hline \multirow{4}{*}{$\begin{array}{l}\text { 3. As regards the registration and storage of the data obtained, } \\
\text { how do you assess your participation? }\end{array}$} & A. Very passive & 1 \\
\hline & B. Passive & 9 \\
\hline & C. Active & 16 \\
\hline & D. Very active & 6 \\
\hline \multirow{4}{*}{$\begin{array}{l}\text { 4. As regards the confidentiality of your patient, how protected } \\
\text { do you think it is? }\end{array}$} & A. Very unprotected & 0 \\
\hline & B. Unprotected & 3 \\
\hline & C. Protected & 18 \\
\hline & D. Very protected & 11 \\
\hline \multirow[t]{4}{*}{ 5. How safe do you consider this device? } & A. Unsafe & 1 \\
\hline & B. Hardly safe & 1 \\
\hline & C. Safe & 25 \\
\hline & D. Very safe & 5 \\
\hline \multirow[t]{3}{*}{ 6. What trust do you have in this equipment? } & A. Low & 0 \\
\hline & B. Moderate & 12 \\
\hline & C. High & 20 \\
\hline \multirow{4}{*}{$\begin{array}{l}\text { 7. What confidence do you have in the accuracy of the diagnosis sent } \\
\text { as a response? }\end{array}$} & A. Minimum & 0 \\
\hline & B. Scarce & 0 \\
\hline & C. Enough & 22 \\
\hline & D. Significant & 10 \\
\hline \multirow{3}{*}{$\begin{array}{l}\text { 8. As regards the quality of the healthcare you bestow, how do you think } \\
\text { it has evolved using this technology? }\end{array}$} & A. Worsened & 0 \\
\hline & B. Not changed & 5 \\
\hline & C. Improved & 27 \\
\hline \multirow{4}{*}{$\begin{array}{l}\text { 9. What benefits do you think the patient might obtain from using this } \\
\text { technology? }\end{array}$} & A. Minimum & 0 \\
\hline & B. Scarce & 1 \\
\hline & C. Moderate & 6 \\
\hline & D. Significant & 25 \\
\hline \multirow{3}{*}{$\begin{array}{l}\text { 10. As regards the doctor-patient relationship, in using this device, } \\
\text { do you think it has: }\end{array}$} & A. Worsened & 1 \\
\hline & B. Not changed & 6 \\
\hline & C. Improved & 25 \\
\hline
\end{tabular}

use, these issues are covered by several frameworks on psychosocial and ethical aspects of emerging health monitoring technologies 10,11,12. Notably, within the last decade growing attention has been paid to ethical, psychosocial and patient-reported issues in health technology assessment in general ${ }^{12}$. The aim of this study was to focus on the ethical and social issues derived from the implementation of this technique. Our study explored the acceptance and expectations of patients and healthcare providers concerning two different aspects: a) the acceptance of the TTECG used in the public healthcare sector in Chile, especially regarding its effectiveness and safety; and b) data protection issues such as confidentiality, privacy and security, raised by the implementation of the TTEGG. 


\section{Conclusion}

Although this study was limited to a small number of participants (patients and healthcare providers), a tendency to approval can be observed concerning the two different areas assessed: high level of acceptability concerning safety and security and high level of expectation was observed in both groups regarding the TTECG.

On the other hand, as the TTECG approach involved flow and storage of patients' data over the procedure, this study concluded for the first time, that the vast majority of participants considered both privacy and confidentiality of patients to be well protected.

\section{Resumo}

O objetivo do presente estudo foi concentrar-se sobre as questões éticas e sociais decorrentes da implementação da eletrocardiografia transtelefônica (TTECG) no sector público da saúde no Chile, estudando a aceitação de pacientes e prestadores de cuidados de saúde e suas expectativas relativas a: (a) eficácia e segurança da TTECG; $e$ (b) questões relacionadas com a proteção de dados, tais como a confidencialidade, privacidade e segurança. Para esse efeito, desenvolvemos dois questionários psicossociais; o primeiro foi dirigido a pacientes recebendo TTECG (quer em serviços de emergência de hospitais ou no distante atendimento primário), e o segundo foi destinado a prestadores de cuidados de saúde envolvidos em qualquer administração ou interpretando-a. Os resultados foram: (a) grande aceitabilidade das TTECG em termos de segurança; (b) a privacidade e a confidencialidade dos pacientes foram consideradas como bem protegidas; $e$ (c) a relação médico-paciente não foi afetada por esse dispositivo.

Eletrocardiografia; Telemedicina; Aceitação pelo Paciente de Cuidados de Saúde; Ética
Another important potential problem using a telemedical approach to health care delivery is that it might negatively affect the doctor-patient relationship. However, the present study shows that the use of this device, TTECG, does not affect the perception of the quality of the doctor-patient relationship. According to the opinion of healthcare providers, and the majority of the patients, this relationship has even improved as a result of this approach. However, it is important to consider that patients were receiving a life-saving intervention, and were in a vulnerable situation that might have impacted their perception of the TTECG. According to the results we considered that TTECG is a good example of a medical device oriented to support expert medical decisions in remote areas coming from specialized centers.

\section{Contributors}

E. Lamas participated in the original idea, design, data collection, analysis and interpretation, and drafting the manuscript. S. Miguel participated in data analysis, and drafting the manuscript. H. Muehlan participated in drafting the manuscript. S. Schmidt participated in drafting the manuscript. R. A. Salinas participated in the original idea, design, data analysis and interpretation, and drafting the manuscript.

\section{Acknowledgments}

The authors wish to thank to Dr. Edgardo Escobar for giving us access to the Telemedicine Center in Santiago de Chile. We would also like to thank Dr. Roberto Del Pino for helping us to collect data. 


\section{References}

1. Bastias G, Pantoja T, Leisewitz T, Zarate V. Health care reform in Chile. CMAJ 2008; 179:1289-92.

2. Burrows J. Inequalities and healthcare reform in Chile: equity of what? J Med Ethics 2008; 34:e13.

3. Julian D. Time as a factor in thrombolytic therapy. Eur Heart J 1990; 11 Suppl F:53-5.

4. Papai G, Racz I, Czuriga D, Szabo G, Edes IF, Edes I. Transtelephonic electrocardiography in the management of patients with acute coronary syndrome. J Electrocardiol 2014; 47:294-9.

5. Escobar E, Véjar M, del Pino R. Lesiones subepicárdicas en Chile (Infarto Agudo del Miocardio con supradesnivel del Segmento ST). Experiencia con telemedicina. Rev Chil Cardiol 2009; 28:73-80.

6. Nazal C, Campos P, Corbalán R, Lanas F. Impacto del plan AUGE en el tratamiento de pacientes con infarto agudo al miocardio con supradesnivel ST, en hospitales chilenos. Rev Méd Chile 2008; 136:1231-9.

7. ASSIST-Assessment and Evaluation Tools for Telemedicine. Vol. 2013. http://www.assist-telemedi cine.net/home.
8. Chau JP, Lee DT, Yu DS, Chow AY, Yu WC, Chair SY et al. A feasibility study to investigate the acceptability and potential effectiveness of a telecare service for older people with chronic obstructive pulmonary disease. Int J Med Inform 2012; 81: 674-82.

9. González Armengol J, Carricondo F, Mingorance C, Gil-Loyzaga P. Telemedicina aplicada a la atención sanitaria urgente: aspectos metodológicos y prácticos. Emergencias 2009; 21:287-94.

10. Lehoux P, Williams-Jones B. Mapping the integration of social and ethical issues in health technology assessment. Int J Technol Assess Health Care $2007 ; 23: 9-16$

11. Muehlan H, Rhode D, Schmidt S. A module for psycho-social assessment of personal health monitoring. Stud Health Technol Inform 2013; 187:95-103.

12. Palm E, Nordgren A, Verweij M, Collste G. Ethically sound technology? Guidelines for interactive ethical assessment of personal health monitoring. Stud Health Technol Inform 2013; 187:105-14.

Submitted on $28 / \mathrm{Jan} / 2014$

Final version resubmitted on $02 / J u n / 2014$

Approved on 10/Jul/2014 